This is the final peer-reviewed accepted manuscript of:

[Construing Justice. Discourses of 'rightness' in the House of Commons: a Diachronic corpus-assisted discourse study]

The final published version is available online at: [https://doi.org/10.1515/9783110604719-008]

Rights / License:

The terms and conditions for the reuse of this version of the manuscript are specified in the publishing policy. For all terms of use and more information see the publisher's website. 


\title{
Construing justice
}

Discourses of 'rightness' in the House of Commons: A diachronic corpus-assisted discourse study

\begin{abstract}
The chapter investigates the construal of 'justice' within a specialized domain of British politics, i.e. the British House of Commons. As a quintessentially abstract concept, justice is very challenging area to investigate empirically through the lens of corpora. By bringing together the methodological and theoretical tools of (critical) discourse analysis and corpus linguistics (Baker 2006, Bayley \& Morley (eds) 2009, Baker \& McEnery (eds) 2015, Miller et al. 2014), the chapter engages with this challenge by examining patterns of evaluative orientation and intersubjective positioning (Martin \& White 2005, Thompson and Hunston 2006) in a diachronic corpus of British parliamentary debates on the issue of (im)migration. The purpose is to further research into the speakers' construal of justice as a complex interplay of discursive, socio-political, and sociocultural (Silverstein 2004) dimensions of what is 'right', vis-a-vis strategies of persuasion and legitimation (van Leeuwen 1996, Reyes 2011). In particular, this study focuses on the analysis of the evaluative construction it is * right as a key contested rhetorical terrain through which the members in this powerful and influential institutional setting position themselves to construe 'justice' in quite distinct ways.
\end{abstract}

Keywords: parliamentary discourse, critical discourse analysis, SFL, global justice, (im)migration

[...] language, a distinctly human capacity, isn't just for registering pleasure and pain. It's about declaring what is just and what is unjust and distinguishing right from wrong. We don't grasp these things silently, and then put words to them; language is the medium through which we discern and deliberate about the good.

M.J. Sandel (2009), Justice: What's the Right Thing to Do?

\section{Introduction}

\subsection{Preamble}


On the $8^{\text {th }}$ of November 2015, the Labour MP and Shadow Home Secretary, Yvette Cooper, initiated an emergency debate "on the Refugee crisis", by citing the words of Philip Noel-Baker, a former Labour MP, who in November 1938, on the verge of the Second World War, delivered his famous 'Kindertransport' speech persuading members in the House to allow persecuted Jewish children to enter the UK. In Noel-Baker's speech, resonating in Cooper's words, the arranged rescue from Nazi Europe was primarily justified on principles of "moral rightness" - a core principle of justice, and indeed, social justice:

Tomorrow may be a hard day for us, but I feel that, by doing the things that are morally right, we shall achieve something which is worthy of the name of the British nation. [Official Report, 21 November 1938; Vol. 341, c. 1456, my italics]

While quoting the words of "authoritative" others is one crucial discursive feature in this specialized domain of political discourse, fulfilling several rhetorical functions (see Bevitori 2005, 2006), the extract is here meant to provide critical input for an investigation into the construal of 'justice' within a specialized domain of British politics. In fact, a cursory look in the Oxford English Dictionary shows that, amongst the many meanings of justice, sense III of the word justice refers to "moral uprightness" as "The quality of being just or right [...]". Likewise, according to Roget's classification system, a lexical resource providing a valuable perspective on semantic relatedness, the word is categorized under 'morality', pertaining to Class VI, Section 4 of the system, which is further sub-classified into the two semantically-related subsets of 'right' and 'virtue' (see also Bevitori 2018: 173).

Since the earliest days, reflections around the conception(s) of justice have always occupied a central position in philosophical debates over the centuries. In particular, according to John Rawls, a leading figure of contemporary political philosophy, justice is "the first virtue of social institutions" (Rawls [1971]1999: 3); ${ }^{2}$ a set of values that should underpin states, politics and the law. The research for this study stems from the underlying assumption that justice is a social and "human construction" (Walzer 1983: 5); indeed, it is also, as Michael J. Sandel (2009: 261) has fittingly observed, "inescapably judgemental". By this the political philosopher means that not only is justice about the right way of distributing things - that is, in accordance

1 Emergency debates in the House of Commons are debates called at short notice on matters that require urgent consideration and, as such, they follow a distinct procedure; see www.parliament.uk. As regards the emergency debate mentioned here, the e-petition entitled "Accept more asylum seekers and increase support for refugee migrants in the UK" received over 245,000 signatures. See https://petition.parliament.uk/archived/petitions/105991 (Last accessed November 2019 ).

2 It must be mentioned that Plato's Republic deals with justice as a virtue of both individuals and the state. For an overview of 'justice as a virtue' in the philosophical debate, see Lebar \& Slote 2016. 
with principles of distributive justice ${ }^{3}$, but also, and perhaps more importantly, about "the right way to value things" (Sandel 2009: 261, my italics).

\subsection{Aims, scope and rationale}

The chapter intends to continue work conducted in the context of an interdisciplinary research project aiming at identifying linguistic and discursive patterns broadly construing justice in the political and institutional setting of parliamentary debates (see Bevitori 2018). As a quintessentially abstract concept, justice may in fact be seen as a crucial site of competing interpretations and, therefore, competing world views, making it a very challenging area to investigate empirically through the lens of corpora. By bringing together the methodological and theoretical tools of (critical) discourse analysis and corpus linguistics, of which more later (Section 3), the present chapter provides an attempt to engage with this challenge by looking into the world of British Parliament and, more specifically, at some evaluative and discursive constructions of speaker orientation and intersubjective positioning (Lemke 1985, 1992, Miller 1999, Martin \& White 2005, Miller \& Johnson 2013, 2014), through which justice may be construed in a specialized diachronic corpus of debates on (im)migration in the British House of Commons. The aim is to further research into the speakers' construal of justice as a complex interplay of discursive, socio-political and, indeed, "socio-cultural" (Silverstein 2004) dimensions of what is just, fair and, indeed, right and moral, vis-a-vis strategies of persuasion and legitimation (inter alia Martín Rojo \& van Dijk 1997, van Leeuwen 1996, van Leeuwen \& Wodak 1999, Reyes 2011), at the intersection with current research revisiting the notion and significance of 'global justice' in contemporary political discourse (Eriksen 2016). ${ }^{4}$ In particular, an investigation into the language of "rightness" is offered as a case-study, providing a complementary and critical layer on previous work on the language of "fairness", as key contested rhetorical terrains in British contemporary politics (Bevitori 2018). In fact, it may be worth pointing out that justice is, by its very essence, a matter of what is right (or just), or conversely, wrong (or

\footnotetext{
3 Distributive justice is broadly concerned with a just distribution of the goods, as well as "the morally proper distribution of rights, duties, material resources and opportunities" (Eriksen 2016: 2). 4 This article is a by-product of research conducted in the context of the project GLOBUS-Reconsidering European Contributions to Global Justice, which received funding from the European Union's Horizon 2020 research and innovation programme under grant agreement n.693609. For more information: http://www.globus.uio.no. Eriksen's (2016) seminal paper investigates the concept of global justice that characterises the EU's external activities by providing a three-dimensional approach - i.e. justice as nondomination, as impartiality, or as mutual recognition.
} 
unjust) - that is, about taking an evaluative and judgemental stance, especially in confrontational and deliberate discourses such as parliamentary debates. To that end, the chapter endeavours to make an empirical contribution to the broad and necessarily interdisciplinary field of corpus-assisted discourse analysis at the crossroads between language, discourse and politics 5 .

The chapter is structured as follows: Section 2 introduces some aspects of parliamentary discourse. The theoretical frameworks underpinning the research will be provided in Section 3 while Section 4 presents the corpus and describes the socio-political context in the period under examination. It will also describe the methodology and briefly report on previous findings. In Section 5, the quantitative and qualitative aspects of analysis will next be dealt with, and, finally, some concluding remarks will follow.

\section{Aspects of parliamentary discourse}

Parliamentary discourse may be understood as institutional discourse, which is "mutually constitutive of a speech community" (Ilie 2006: 191). Ilie usefully highlights its main features from a two-fold perspective. 'Pragma-linguistically', it is characterized by institutionalized discursive elements, based on a set of ritualized and rule-bound interaction strategies (see also Bayley 2004). Rules are provided by Erskine May, the most authoritative reference book on British parliamentary procedures, ${ }^{6}$ and apply to a variety of features, such as forms of address and turn-taking, amongst others (for an overview see Ilie 2006). 'Rhetorically', parliamentary discourse belongs to the deliberative genre - an oratorical, confrontational discourse, or "deliberate dispute" (Adams 1999: 1) aimed at discussing and assessing benefits and constraints of a future course of action.

Over the last two decades, research on parliamentary discourse from linguistic perspectives has increased exponentially in many different fields of study, involving a diversity of methodological approaches (Wodak \& van Dijk (eds) 2000, Bayley (ed.) 2004, Ilie (ed.) 2010, Ihalainen, Ilie \& Palonen (eds) 2016). While a number of studies have focused on some of its distinctive rhetorical features, such as interruptions, forms of $\mathrm{im}$ /politeness and metadiscursive features (Harris 2001, Bevitori 2004, Ilie 2004), contributions from critical discourse analytical perspectives in this area have primarily centered on a number of discursive mechanisms,

5 For a discussion of different interdisciplinary approaches in corpus linguistics and CADS, see Ancarno 2018.

6

https://www.parliament.uk/site-information/glossary/erskine-may. See also Boulton et al. (1989). 
pointing to a rhetoric and anti-rhetoric of racism and discrimination (inter alia van Dijk 1993, 2000; Martín Rojo \& van Dijk 1997; Wodak \& van Dijk (eds) 2000).

More specifically, van Dijk (2000: 47) argues that parliamentary discourse is characterized by a number of "prototypical" albeit "non-exclusive" features, which constitute relevant categories in the reproduction of discriminatory practices related to ethnic issues. Discourse in this institutional setting, therefore, is not simply a linguistic activity per se but a complex set of "institutional actions", which act to perform an array of "political things" (van Dijk 2000: 20). In other words, and paraphrasing Austin (1962), saying within this institutional setting means acting politically either by endorsing or contesting a bill, justifying or legitimizing a course of action and, perhaps even more significantly, encouraging different world views. As a pivotal area in much scholarly research from critical discourse analysis (henceforth CDA) perspectives, an understanding of the role political institutions play in the political processes is of fundamental importance as decisions made in this highly influential institutional setting affect people's everyday life.

Other contributions of relevance for this study are in the field of corpus linguistics combined with discourse analysis with the aim of identifying the linguistic construal of the speaker's evaluative stance and intersubjective positioning (Miller 1999, Bevitori 2005, 2006), at the intersection of different parameters such as institutional role, party affiliation and gender (Bevitori 2007, 2010; Bayley \& Bevitori 2009; Miller \& Johnson 2014). In particular, Miller and Johnson (2014) focus on the investigation of the lexical, or function 'bundle' (Halliday 2002a [1985]: 262, Biber \& Conrad 1999; for a development, Biber, Conrad \& Cortes 2004, Partington \& Morley 2004), it is * time as an idiosyncratic evaluative choice in US politics, which, as they show, is typically chosen by members of the party in opposition to attack and criticize the opponents. Broadly speaking, inquiry in this area is based on the assumption that parliamentary discourse is intrinsically “dialogical" (Bakhtin 1981), being characterized by a broad range of intertextual and, indeed, interdiscursivity features (Fairclough 1992). In fact, as Lemke (1985: 285) usefully reminds us, any speech community hinges on different systems of intertextuality; a set of "preferred discourses", which are "intertextually and contratextually interwoven" (Bayley 2004: 24) as MPs' talk and act in response to what is said both in the House but also elsewhere, in other arenas of debate.

\section{Theoretical frameworks}

The research for this study relies on the combination of corpus linguistics techniques with CDA methodologies, firmly grounded within systemic functional linguistics (SFL) and appraisal theory (Martin \& Rose 2003, Halliday \& Matthiesen 2004, Martin \& White 2005, Thompson \& Hunston) 2006). Corpus linguistics at the interface with the analysis of discourse, as the two main "twin pillars of research" (Sinclair 2004: 10), has in 
fact been a very productive and dynamic field of study over the last two decades. Since pioneering works (Hardt-Mautner 1995, Stubbs 1996), research attempting to reconcile corpus techniques with discourse analytical methods, from a number of different perspectives, is now well established (inter alia Partington 2004, Baker 2006, Bayley \& Morley (eds) 2009, Partington, Duguid \& Taylor 2013, Baker \& McEnery (eds) 2015, Miller et al. 2014 for a critical review, Taylor \& Marchi (eds) 2018). The approach typically implies not only a cross-feeding interaction of quantitative and qualitative dimensions of investigation, but also involves an interrelated set of analytical processes, procedures and techniques. As Halliday (2005: 75) cogently reminds us:

Qualitatively, there will be certain key discourses which carry special value, either intrinsically, because they somehow distil the semiotic essence of their moment in space-time, or extrinsically because they played a critical part in the ongoing material events [. . .]. Quantitatively, on the other hand, dominant semiotic motifs emerge more or less gradually over time; to access and evaluate these one needs a corpus of contextualized discourses that can be examined and interpreted as whole.

While computer methods are of great help in tracing and counting linguistic patterns, and thereby redressing the thorny question of selective analysis, interpretation obviously lies in the eyes of the beholder. In fact, as argued elsewhere (see, for example, Bayley \& Bevitori 2009, Baker 2012), the role of the researcher is crucial and cannot be isolated from her/his socio-political standpoint. CDA is a case in point. As a multifaceted approach to the analysis of discourse, it is concerned with the way in which ideology and power are articulated, sustained and challenged in language. Its main goal is to emphasize inequalities as well as abuses of power; however, in spite of the enormous contribution in different fields of analysis, CDA has also attracted some criticism, in particular as regards the arbitrary selection of ad hoc linguistic features to fit one's "own agenda" (Widdowson 1995: 148). Thus, corpus techniques providing a practical and helpful way to avoid the "cherry picking" may be seen as instrumental to complement the qualitative analysis of discourse based on robust, empirical, quantitative data (Baker 2006, 2012), although some caution is warranted in order to prevent counting only "what is easy to count" (Stubbs \& Gerbig 1993: 78).

While corpus linguistics techniques have provided a useful perspective to the study of evaluative constructions in many valuable studies across different genres, or discourse types (Hunston 2011 for an overview), the purpose of this research is to carry out a critical discourse and meaning analysis of the ways in which lexicogrammatical features, having "a greater-than random tendency to occur" (Halliday \& Martin 1993: 54, Bayley 2004, Miller \& Johnson 2014, Miller et al. 2014), are typically co-selected in a defined 
situational/political context with a dual scope: "globally", in terms of register (here British parliamentary discourse), and "locally" - that is, the specific topic(s) being debated (here (im)migration).

In the present study, the qualitative analysis will rely on a set of theoretical tools provided by systemic functional linguists and, in particular, appraisal theory, consisting in a development of the study of SFL interpersonal meaning, and evaluative language construing "attitude towards person, situation or other entity [...] located within a societal value-system" (Hunston 2011: 14). Appraisal deals with semantic resources which speakers or writers employ "to negotiate emotions, judgments and valuations" (Martin 2000: 145; see also Martin \& Rose 2003, Martin \& White 2005); in other words, the system is meant to explore how speakers and writers commonly express their judgmental stance on people, material objects, events and states of affairs and, as well as how they negotiate meanings by aligning/disaligning with the different viewpoints expressed by members in a community. A detailed examination of the system is beyond the scope of this work, and due to space constraints, I will here briefly refer solely to the key elements that will be instrumental to the analysis. The system subsumes three main sub-systems (Martin \& White 2005: 35): 'attitude', i.e. "ways of feeling”, 'graduation', defined as "the way in which feelings are amplified", and 'engagement', or "the play of voices around opinions in discourse". Attitude is of particular interest here. This subsystem deals in fact with language resources falling into three main categories: resources for expressing emotions ('affect'), which is "institutionalized" as Martin has it (2000: 147) in the category of 'judgment', or resources for assessing human behaviour in accordance with normative, ethical, and moral principles, as well as 'appreciation', i.e. resources for construing the value of things, according to one's aesthetic preferences. Language resources in each category can express positive or negative values, which also function to "align/disalign" interactants in the negotiation of meanings.

Indeed, in order to appreciate the relevance of the framework for the study of discourse in different settings, it may be worth pointing out that the in SFL the notion of register is crucial. By linking aspects of language in context, such as the role of the speaker(s) and the nature of debate (basically, the "who" and "what"), with specific linguistic features, the system does provides a theory explaining why certain features tend to occur, or prevail, under certain circumstances. More specifically, it is argued that instantiations of "rightness" in the debates, similarly to those of "fairness", as discussed in Bevitori (2018), here briefly reported (Section 4.2), and integrated in the analysis where relevant (Section 5), act concurrently both at a "global" and "local" level to construe interpersonal meanings of justice within this specific institutional domain.

\section{Corpus and methodology}


4.1 Data and socio-political context

The data for this study have been gathered from Hansard Online, the Official Report of parliamentary debates, freely available though an online database, which contains the transcribed (verbatim) speeches held in each House in Parliament. For the purpose of this study, a specialized corpus of debates in the Commons on the wide-ranging topic of (im)migration, incuding asylum ad refugees, was compiled. This corpus (henceforth referred to as HocMigra corpus) consists of the complete set of transcriptions of all the sittings held in the House of Commons in the span of time between 2010 and 2015, containing the search words *migra*, asylum, refugee*, and Calais, which amounts to 147 full debates, in the range of approximately 903,000 running words. ${ }^{7}$

As regards the period considered in this study, the time is opportune as the 2010 general elections produced, for the first time in 26 years, a hung Parliament in which no party enjoyed an overall majority. This undoubtedly marked a historic shift which saw the formation of the coalition between the Conservatives and the Liberal Democrats, resulting in a number of reforms. Indeed, according to Russell (2016: 99), parliamentary power gradually increased, pointing to a transition toward a "more assertive and effective" role. While in the period between 2010 and 2015, a number of reforms were introduced by the Coalition Government, particularly as regards eligibility criteria for visas and welfare benefits for immigrants, what raised major disagreement between the parties was the issue of "net migration"- that is, the difference between the number of people who move temporarily to the UK and those who depart to live elsewhere for the same periods. Throughout the period, as a report published in the House of Commons Library suggests ${ }^{8}$, the aim of the Coalition Government was to reduce the levels of "net migration" from the "hundreds of thousands to the tens of thousands" in the endeavor to create a "hostile environment" for irregular immigrants (see Yeo 2017); an effort "consistent with the 'pragmatic' tradition of UK policy-making" (Zotti forthcoming), and perhaps, a feature of British identity itself (see Kelly 2003). For that purpose, new measures were introduced by the 2014 Immigration Act, which was subsequently developed and reinforced with the new Immigration Bill in 2016.

7 The Official Report of parliamentary debates available online at https://hansard.parliament.uk [Accessed March 2017]. The use of wildcard in the search term * migra* allowed the retrieval of all debates both on immigration and migration.

8 'Immigration and Asylum: changes made by the Coalition Government 2010-2015' available at: http://researchbriefings.parliament.uk/ResearchBriefing/Summary/SN05829\#fullreport [Last accessed November 2019] 
The breakdown of the corpus per year, including both the number of debates and the number of running words, is provided in Table 1.

Tab 1. HocMigra Diachronic Corpus (2010-2015)

\begin{tabular}{lllllll}
\hline Year & $\mathbf{2 0 1 0}$ & $\mathbf{2 0 1 1}$ & $\mathbf{2 0 1 2}$ & $\mathbf{2 0 1 3}$ & $\mathbf{2 0 1 4}$ & $\mathbf{2 0 1 5}$ \\
\hline $\begin{array}{l}\text { Running } \\
\text { words }\end{array}$ & 72,196 & 39,928 & 45,340 & 212,857 & 208,406 & 346,882 \\
\hline No. of debates & 17 & 20 & 12 & 25 & 29 & 44 \\
\hline
\end{tabular}

As can immediately be observed, in spite of a decline in terms of number of debates in 2012, the number of debate (and hence time) devoted to issues of (im)migration tends to increase in the House, reaching in 2015 a dramatic surge as a result of the so-called "migration crisis". In fact, the 2015 general elections marked a new turning point. Winning by a narrow majority (51\%), the Conservative party gained 330 seats overall (24 more than those gained in the previous election), while the Liberal Democrats experienced a massive loss of seats. As regards the two major parties in Opposition, the Labour Party lost 26 seats since the previous period, while the Scottish National Party became the third largest party in the UK, gaining the highest share of seats, as well as votes at a General Election. ${ }^{9}$ Figure 1 shows the distribution of the number of debates held in the House according to the different topics of debate.

9 See General Elections 2015, Briefing Paper at:

https://researchbriefings.parliament.uk/ResearchBriefing/Summary/CBP-7186 


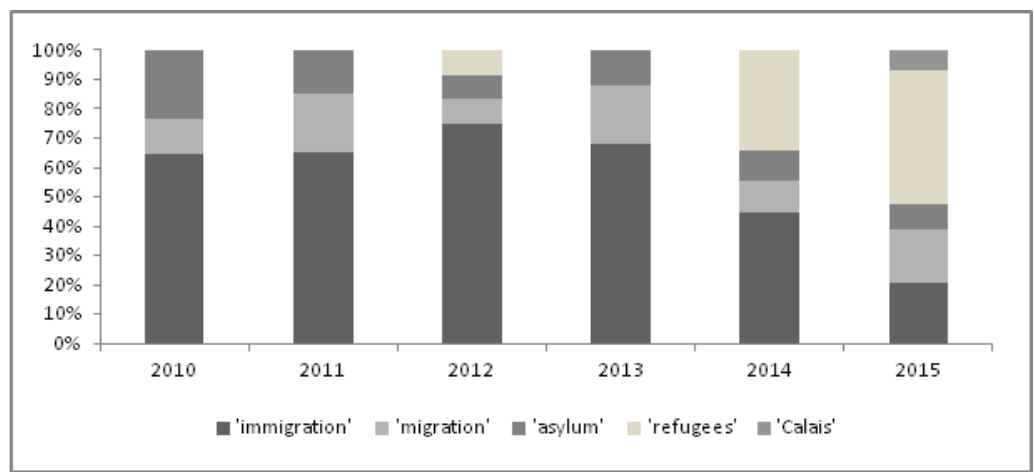

Figure 1. Breakdown of the number of debates by topic over time

While the number of debates devoted to asylum and migration remains relatively stable over time, the number of debates on immigration tends to increase, reaching a peak in 2012, but progressively decreases to its lowest point in 2015. In contrast, and perhaps unsurprisingly, the years 2014 and, particularly 2015, saw a rapid and dramatic increase in the number of debates about refugees covering, respectively, one third and a half of all debates held in the House. As observed in a previous study (Bevitori 2018), the year 2015 was in fact crucial for the global "migration crisis", which explains the dramatic increase of the number of debates in the House, as will discussed later (Section 5.1).

\subsection{Methodology}

As has been mentioned, the main methodology is grounded in corpus-assisted analysis of evaluative constructions which are seen to broadly construe justice in a domain of political and institutional discourse. A combination of corpus-assisted software tools, such as WordSmith 6.0 (Scott 2015) and SketchEngine (Kilgariff et al. 2004) were used, beginning with quantitative data as a starting point, and then moving backwards and forwards, or "shunting" (Halliday ([1961]2002: 45), between concordance lines to text, as well as from texts to the wider context and discourse, to detect dominant semantic motifs. Meaning patterns emerging as statistically salient (i.e. in terms of frequency) are then examined in the attempt to shed light on some discursive mechanisms of legitimation construing justice. This is made possible by the relatively small size of the corpus itself and by the use of the software allowing access to full texts. Corpus data, in fact, provide decontextualized information about meaning patterns, which can be used as entry points for a more fine- 
grained analysis of discourse. The procedure enables the researcher to contextualize occurrences, and thereby discern how the speakers in the House construe the issue they are addressing, and enact their role(s) within the framework of the parliamentary event.

Previous findings on a subset of the diachronic corpus being used here have identified some preferred, as well as dispreferred, lexical choices through which members of parliament (MPs) enact their political stance towards issues of justice as regards (im)migration, with a focus on a key year for the migration crisis, i.e. 2015. In particular, while the quantitative analysis of the lexical items fair, moral and humane are shown to be significantly frequent as compared to the reference corpora, a closer, qualitative examination of the former (fair) shows that the term tends to typically co-occur with the word 'share', in the noun groups 'fair share of' and 'fair share to/on'. As argued in Bevitori (2018), this seems to suggest that the different meaning patterns associated with these three-word clusters encode different ideological positionings (Bevitori 2018: 175-180 for a discussion). Thus, the present study aims to provide a diachronic extension and further elaboration of previous results, possibly enhancing a more complex and nuanced picture. In particular, the analysis will revolve around lexicogrammatical constructions of the phrase it is * right as a select case-study in order to investigate its behaviour over time and across party membership, as well as to assess whether and how attitudinal meanings and ideological positioning are being construed over time. Moreover, on closer inspection, since the analysis of the collocational patterns of the phrase from a diachronic perspective reveals that the word moral tends to be increasingly associated with discourse of 'rightness', it was deemed useful to look into this further.

As regards the quantitative dimension, two reference corpora of parliamentary speeches are employed for comparative purposes: the House of Commons (HoC2003) and the Hansard Corpus of British Parliament 1803-2005. The HoC2003 corpis a collection of parliamentary speeches held in the House of Commons on the Iraq war in 2003, amounting to circa 980,000 running words, which was purposefully compiled for previous research (see Bevitori 2007: 143, Bayley \& Bevitori 2009: 81-82). The Hansard Corpus is a text collection of British of parliamentary speeches delivered both in the House of Commons and in the House of Lords in the period of time between 1805 and 2005. The corpus was created by the SAMUELS Consortium, and amounts to approximately 7.5 billion speeches in the region of 16 billion words ${ }^{10}$. This extremely useful resource is enriched by semantically-related search words, and was thus used as a benchmark for categorization as well as frequency (see also Bevitori 2018: 173-174).

10 The corpus is freely available at: https://www.english-corpora.org/hansard/ 


\section{Embedding justice: analysing "rightness"}

5.1 it is * right*: Quantitative analysis

There are 175 instances of the phrase it is * right that/to in the HoCMigra corpus corresponding to a normalized figure of 0.19 per thousand words. As Table 2 shows, the phrase occurs more frequently in the HoCMigra corpus as compared to both HoC2003(Iraq) and Hansard(1805-2005), the latter showing the same figure in the $B N C$.

Table 2. Relative frequency of it is * right to/that across corpora

\begin{tabular}{lllc} 
HocMigra & HoC2003-Iraq & Hansard & BNC \\
0.19 & 0.06 & 0.001 & 0.001 \\
\hline
\end{tabular}

A look at its distribution over time, however, reveals that its frequency is not stable but tends to escalate considerably, from 0.08 in 2010 to 0.26 in 2012, which might be considered statistically significant in spite of the relatively small size of the corpus.This is followed by a drop in 2013 and by a new steady increase to 0.24 in 2015 (Figure 2), which might find an explanation in the emergence of a number of debates about "refugees" in 2012, followed as explained, by an upsurge in 2014 and, more than ever, in 2015, as explained earlier (see Figure 1).

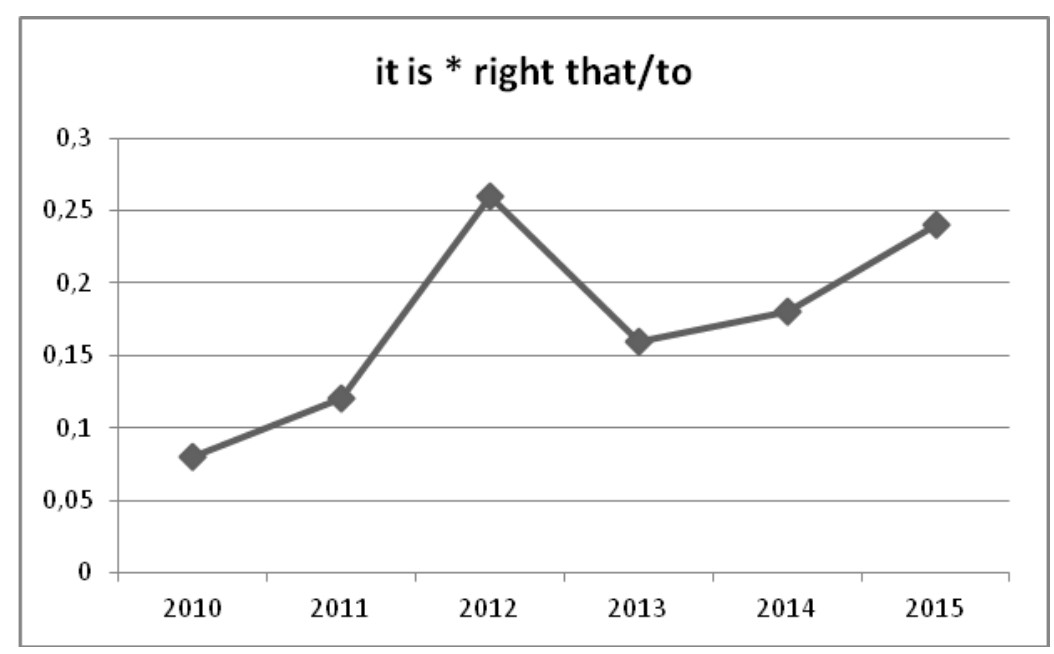


Figure 2. Relative frequency of it is right * to/that over time

Interestingly, with reference to our diachronic corpus and the aim of this study, the phrase tends to be more consistently used by Conservatives, $83 \%$ of all instances, of which almost half are uttered by members of the cabinet (38\%), as illustrated in Figure 3.

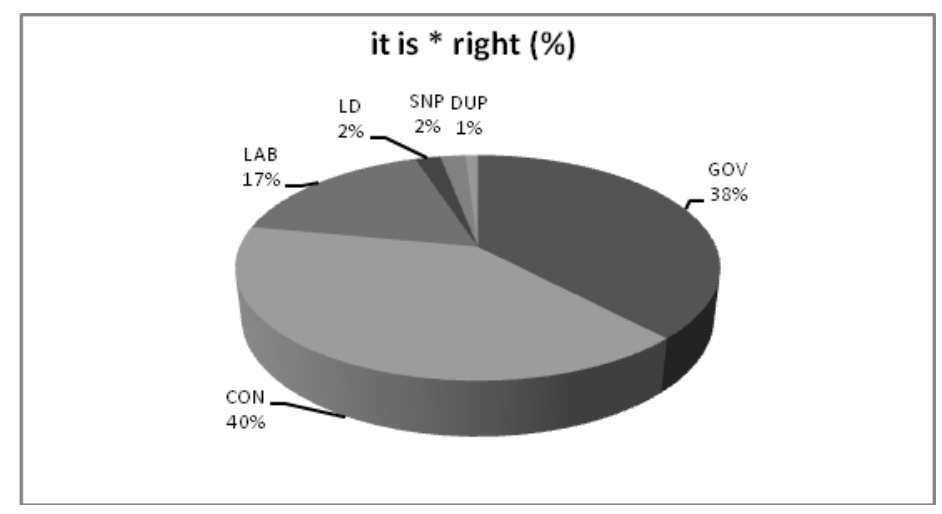

Figure 3. Instances of it is * right to by party members (\%)

As regards the opposition, the Labour party features more strongly, even though with only $17 \%$, followed by the SNP (3\%). This is a clear indication of the fact that the phrase is a main feature of Government's discourse, as well as members supporting the Government, although a word of caution is needed as this corpus is not annotated in terms of speaker or party roles and, therefore, data may be skewed by the amount of time the different parties speak in the debates. However, by showing the percentage of occurrences over the total of occurrences in the corpus, the figure provides some hints worth of further empirical investigation. Bearing in mind these quantitative results, the analysis of some meaningful patterns will be dealt with in the following section.

\section{2 it is * right: Qualitative analysis}

As has been observed in the introduction, it may be worth emphasizing once again that while the phrase it is * right is in itself an evaluative construction with a clear interpersonal function, justice is fundamentally in itself about taking an evaluative stance on what is or is not right. Attitudinally, the phrase realizes meanings of 
'judgment', as a value of social sanction, which might involve, to some extent, the lexicalization of modal meanings of obligation. The analysis of the data show that the phrase is complemented by that in $73 \%$ of all instances; moreover, an initial count of processes and participants reveals that the personal pronoun we is the most frequent collocate as well as the most frequent participant in the immediate right of the node phrase it is * right that, occurring 53 times, corresponding to $30 \%$ of all instances across the whole corpus. However, variations over time and space (i.e. in terms of events as explained above, see Figure 1) occur, and will be dealt with in more detail in the next sub-sections.

\subsubsection{What is it * right that WE do?}

An analysis of typical patterns of co-selection shows that the phrase 'it is * right that + we' yields interesting insights into members' intersubjective and ideological positioning on the issue at stake. To begin with, in the span of time between 2010 and 2013, this pronominal choice is typically selected by Government members in $25 \%$ of all instances, and expresses the Government's position on the "rightness" of actions to be taken. The pronoun we is employed as the Actor, typically co-selected with material processes such as do, act, support, take, of which the following extract provides an example:

(1) Mr Mark Harper (Minister for Immigration): It is absolutely right that we support those legitimate students who are here legally, complying with the terms of the basis on which they are here. However, it is also right that we take firm action against institutions that fail to carry out the steps they are supposed to carry out if they are to be trusted sponsors. The public would expect that. (06.09.2012)

A first observation as regards the use of we is in order. In fact, its use shows some ambiguity, which can be seen as strategic in the construction of affiliation within this institutional context. This pronominal choice, which is indeed very frequent in political language as a large number of studies have demonstrated after Wilson's seminal study (1991), while clearly referring to the Government, also includes members present in the House, party members, as well as the British people at large. It thus may be seen as a clear marker of responsibility in bringing the community together around certain values. Instances of the phrase in the corpus seem to drive the debate not only towards "what is owed" to community members, as a key tenet of 'justice', 
at least in the Aristotelian sense ${ }^{11}$, but also towards on "who should count as a member and which community is relevant" (Fraser 2005: 72, see also Eriksen 2016). The following example provides an illustration:

(2) Damian Green (Minister for Immigration): Many of our communities have been enriched by the contribution of generations of migrants, and it is absolutely right that in today's competitive global economy we attract the brightest and the best to this country. (12.12.2011)

Interestingly, the noun phrase the right people occurs 9 times in the debates held in this span of time, and particularly in those on Immigration in 2013, showing a semantic preference for verbs such as 'getting' or 'encouraging' the right type of immigrant, as shown in the sample concordances below:

Sample Concordances of 'the right people'

on system, to ensure that the right people can get in and the rowth; it is about getting the right people in, with the skill because they cannot get the right people from the domestic ration and ensuring that the right people come to the UK. I system that encourages the right people to come here and

On the one hand, the semantic motif of "taking action" to control immigration by reducing "net migration", implying selecting criteria to choose the "right" immigrant, tends to predominate in the discourse instantiated by the Government, as illustrated by the following example:

(3) Mrs Theresa May (Secretary of State for Home Department): I have never been somebody who says I expect the population of the UK to be a certain figure by a certain period of time, but I think it is right that, by taking these actions, the Government will be reducing net migration, and that will have an impact on the matter the right hon. Gentleman raises. (11.06.2012)

\footnotetext{
${ }^{11}$ See Aristotle, Nicomachean Ethics, Book II
} 
On the other hand, "doing the talking", and by doing so urging the Government to carry out actions in order to limit immigration, is typically instantiated in Conservatives' discourse. Here, patterns of co-selection reveal that the phrase 'is right that + we' is typically followed by verbal processes such as have a debate, discuss, consider, address, talk, acting to build solidarity with the Government:

(4) Richard Fuller (Con): It is right that we have a debate about the number of people allowed into this country, the growth of our population and whether public services can manage. That is exactly right; we should be doing that. Equally, it is right that we talk about the efficiency and effectiveness of our border controls, so that we can hear the Minister, as he did yesterday so admirably, explain how we are managing to improve the situation and get our borders under control. (22.10.2013)

Linguistic resources of positive judgement are deeply interrelated with resources of positive appreciation either in terms of reaction (so admirably) as well as valuation (efficiency and effectiveness), pointing to what can be dubbed as an exemplar of 'institutionalised affect' (Martin \& White 2005: 45) - that is, a co-patterning of judgment resources construing an emotional response within this institutional register. The two interrelated predominant themes are those of border control, which involves its efficient management, and a focus on the national interest based on normative principles of justice at the interface with issues of legality/illegality:

(5) Theresa May (Secretary of State): My hon. Friend is absolutely right. I think that members of the public will say it is right that we are fair to people living in the UK and to those who have come here legally, and that we ensure that those who are here illegally do not find it easy to stay and that we are able to remove them. $(22.10 .2013)$

(6) Mark Pritchard (Con): I believe we should and the Government appears to think the same, or I think the same as the Government's, so it is a matter of how we do it. It is right and fair for the British taxpayer and the British people that we do so. (22.04.2013)

A pragmatic, anti-immigrant stance is thus ideologically encoded in the grammar of this function bundle (Halliday 2002a [1985]: 262), where the British people, and especially taxpayers, are typically construed as 
the main beneficiary of a "fair" system (see also Bevitori 2018: 79). In other words, rightness and fairness are expounded in terms of a utilitarian view of justice, one that prioritises the interests and values of their respective communities, and sees the protection of an external border as a fundamental duty of the governments. ${ }^{12}$ This may be confirmed by looking at instances of the prepositional phrase right for, whose most frequent collocates include us (8), Britain/UK(6), this country/people in this country (3), covering more than half of all instances. ${ }^{13}$

To sum up, 'it is right that + we' is typically instantiated by the government and tends to foster an idea of "selective" justice. The notion of selectivity in fact seems to lie at the very heart of any conception of 'border'; indeed, as argued by Mau et al. (2011: 48), liberal states aim at "making their borders more selective" since the main purpose of border control is to discriminate between desired and undesired flows of populations. However, it must also be noted that looking at the corpus from a diachronic perspective, debates on Immigration overwhelmingly prevail in this span of time, between 2010 and 2013 (as discussed above; see also in Figure 3), and are usually initiated by cabinet ministers, aiming at providing justification, or legitimation, of the proposed measures (see also van Dijk 2000: 69). This notwithstanding, some variations to this pattern occur, particularly in the following years.

\subsubsection{What is it right that WE should be doing?}

As noted, the year 2014 marks a crucial turning point. The numbers of debates around migration, asylum and, particularly refugees began to increase dramatically due to the migration crisis across Europe, which reached its peak in 2015 but was already present in 2014. In line with previous research on parliamentary debates on immigration and, particularly, as an issue of discrimination and racism (Wodak \& van Dijk (eds) 2000), discourses of rightness and fairness advanced by members of the opposition emerging in this period tend to foreground a different construal of 'justice'. Typical collocates of the phrase, in fact, show a clear semantic preference for the motifs of helping and caring as the following extract from a debate on the UNHCR Syrian Refugee Programme at the beginning of 2014 may illustrate:

12 From the perspective of the Globus' framework as mentioned earlier (see note 4), this would imply a definition of justice as-non-domination (see Eriksen 2016).

${ }^{13}$ Unless otherwise specified, the span was set at 5L/5R, and both the minimum frequency for collocates and the minimum MI score was generated automatically by the default setting provided by Wordsmith Tools 
(7) Yvette Cooper (Lab): I know he will agree that many of those refugees want to return to their homes and stay in the region, but it is right that we provide additional assistance to those who are most vulnerable. (24.01.2014)

Findings point to a strong co-selection of linguistic resources expressing the necessity to contribute to a common effort in supporting decisions at an international, and European level; in particular, the modal operator should co-occurs in $26 \%$ of all instances:

(8) Alison McGovern (Lab): Over the 12 months of 2013, 1.1 million people became refugees or asylum seekers, while just 415,000 returned to their countries of origin. [...] In the light of such figures, it is absolutely right that we should discuss what we can do both to pre-empt the process of people becoming refugees through conflict prevention and poverty alleviation (22.07.2014)

Data also suggest that meanings of duty and obligation are thus a recurrent feature of the discourse instantiated by the opposition, in particular to criticise the government's line of conduct. Humanitarian values focussing on helping and assisting the most vulnerable in society are closely associated with legal obligations provided by international agreements acting as a guiding principle: Angus Robertson (SNP): In these awful times for the poor people of Syria, it is right to provide aid and support in the region directly. It is also, however, a duty and humanitarian obligation to do whatever we can to help refugees closer to home. The lessons of history are plain to see. [...] The UK Government have belatedly accepted the case to accept a limited number of refugees. In times like these, we need political leadership to explain why helping refugees is the right thing to do and get on with it. (29.01.2014)

This passage shows a number of strategies worthy of attention. First of all, through resources of negative judgment as 'institutionalised affect' (awful times, poor people), the MP triggers an emotional reaction and invites the audience to empathise with the people of Syria. Moreover, the adjective right as a premodifier of thing in the nominal group the right thing expresses a positive evaluation, in the subsystem of appreciation, 
invoking a negative judgment on the government's conduct and, at the same time, recommending a different line of action. At the same time, the combination of meanings at an ideational as well interpersonal level of instantiation (transitivity and appraisal) or 'coupling' (Martin 2000: 163-164) have a crucial role on how MP speakers act to affiliate with their hearer(s), and are instrumental in providing a "moral" legitimation for an intended course of action (see also Bevitori 2018: 177). A closer look at concordances of patterns of 'the right + noun' reveals that the thing is the most frequent collocate within the same span of 5 words on each side, occurring 56 times, and with a relative frequency of 0.06 . Furthermore, $84 \%$ of all instances are found in the period between 2014 and 2015 and the pattern is recurrently used either to praise or criticize the government's behaviour:

(10) Conor Murphy (SF): We should support them when they [i.e. the Government] do the right thing and continue to cajole and encourage them when they are not fulfilling their responsibilities. (29.01.2014)

In contrast, when a "humanitarian" discourse is invoked by government members, the typical pattern of coselection reveals a recurrent use of disclaimers and, in particular, formulations of concede-counter pairing it is * right...but, construing an audience that is positioned to accept that aid is in place, being right and proper under certain conditions, thus naturalizing the audience to partially reject it based on different assumptions:

(11) Nicola Blackwood (Con) It is unquestionably right that we should offer refuge to the most vulnerable refugees, and I particularly welcome the focus on survivors of torture and sexual violence, many of whom remain at risk even in refugee settlements. But the effectiveness of this scheme will depend on early identification and access to the right package of specialist support in the UK. (29.01.2014)

(12) The Prime Minister (Mr David Cameron): It is absolutely right that Britain should fulfil its moral responsibility to help the refugees, just as we have done so proudly throughout our history. But in doing so, we must use our head and our heart by pursuing a comprehensive approach that tackles the causes of the problem as well as the consequences. (07.09.2015) 
Through the semantic pairing and rhetorical move it is * right...but, members of the party in government and the government itself concede to be sharing common values with the audience (helping those in need), operating within legal international obligations; at the same time, however, the empathic move is soon challenged by the countering move. The concede-counter pairing is, then, a key rhetorical feature and a powerful tool in the complex interplay between power and solidarity (see also Bayley 2007); indeed, it provides a core legitimation function in the negotiation of meanings of rightness and, indeed, 'moral' rightness as a claim of justice. In fact, while the reference to the collective memory of the past, ('as we have done so proudly throughout history'), expressed in the above example (12), is one of the preferred topoi, or mechanisms, of legitimation (van Dijk 2000, van Leuwen 1996) in this institutional setting, our corpus data show that this is often associated with meanings of obligations or duty and responsibility. I will now briefly address this issue in the following section.

\subsubsection{On rightness and morality}

As a last point, and for reasons explained earlier, I shall now touch on the analysis of moral. Like justice, morality, is a very abstract category and can be conceived and lexicalized in a number of different ways. In the present study, and for the sake of this work, the analysis will investigate the term moral beginning with its frequency as a starting point. In fact, quantitative data show that the search term moral has a relative frequency of 0.09 per thousand words in the HoCMigra corpus, which is lower than the Hoc2003(Iraq) corpus (0.11), but considerably higher than both the Hansard Corpus (0.001), and the general reference corpus BNC (0.08). Figure 4 illustrates its frequency in the whole MigraCorpus as well as across reference corpora.

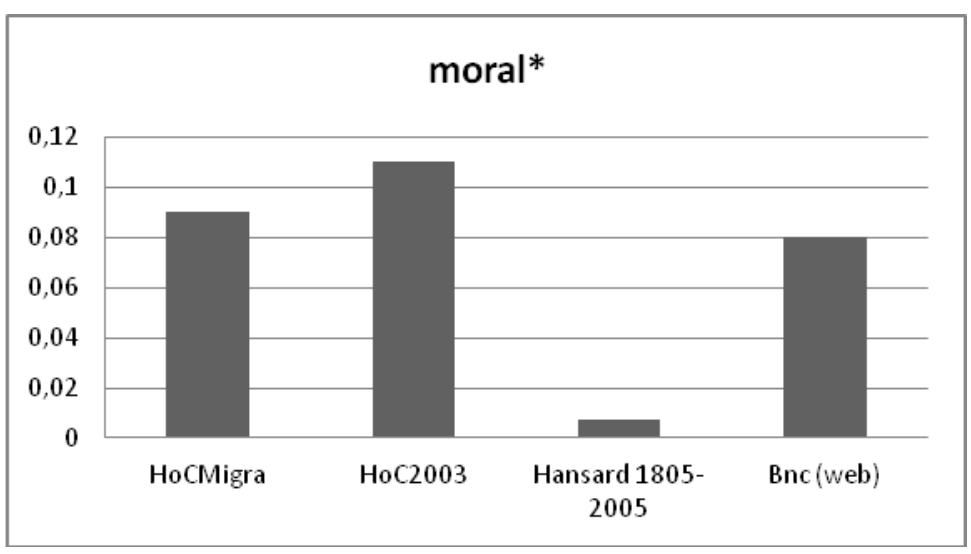

Figure 4: Relative frequency of moral (per thousand words) across corpora 
First of all, it is worth pointing out that the higher frequency of the term in the Hoc2003(Iraq) may undoubtedly be due to the nature of the corpus itself, where the issue being debated in the Commons, i.e. the war in Iraq was highly controversial and morally loaded (see also Bayley \& Bevitori 2009). As regards the corpus here under study, the breakdown of instances of moral in the HocMigra corpus, shows that its frequency is substantially higher in 2015 , covering over $85 \%$ of all instances, which may be clearly explained in terms of the migration crisis; in fact, the overwhelming majority ity of all instances occur in debates about refugees and humanitarian crisis.

The analysis of collocates in the corpus shows that the adjective moral as a pre-modifier is typically coselected with nouns in the semantic set of 'duty', which include: responsibilities (11 occurrences), obligation (10), duty (4), imperative (3), pointing to the strong and urgent necessity to act in order to provide humanitarian help and show solidarity:

(13) Yvette Cooper (Lab): It is not right to provide humanitarian assistance? It is not our moral responsibility? (21.10.2014)

(14) Ian Lucas (Lab): Lest we forget, this Government, supported by Her Majesty's Opposition, backed military intervention in Libya. The people who are drowning in the Mediterranean are fleeing the chaos in that country. Is there not a simple moral imperative? Do we not have a moral obligation to those people until there is a stable Government in Libya? (30.10.2014)

Furthermore, the use of interrogatives, as the two examples show, is also a recurrent rhetorical device typically used by opposition members, in particular by backbenchers enacting the role of the 'scrutinizer', and aiming at rebuking the government for its failure to comply with humanitarian principles:

Joanna Cherry (SNP): That is the sort of humanity we need, it is the international initiative that refugees need and it is the moral compass that I hope will make the UK Government wake up to their now shameful position on the international stage. (08.09.2015)

As noted, while most of the debate about acting morally in the opposition's discourse is semantically associated with duty and obligations emphasising an internationally-oriented form of humanitarism (Walzer 2011), the language of rightness in government's discourse highlights a nation-centred concept of justice foregrounding 
a more practical and pragmatic stance emphasising national interests and values. In other words, what is "morally right", or what serves as as a guide for a 'morally' appropriate behaviour, as metaphorically expressed by one MP as the "moral compass" ( see example 15) is therefore a crucial site of the struggle over meanings and, at the same time, a blatantly contested domain:

(16) Sir Gerald Kaufman (Lab) I am afraid that the phrase 'morally right' is somewhat ambiguous under this Government. (08.09.2015)

\section{Conclusions}

The aim of this chapter was to explore discourses of rightness broadly seen to construe justice within the specialized institutional setting of the British House of Commons, and as regards a highly contested area of policy-making: (im)migration. Looking at the corpus as a "treasury of acts of meaning which can be explored and interrogated from all illuminating angles" (Halliday 2002b: 406, Miller et al. 2014), the study has attempted to shed light on some of the linguistic and discursive mechanisms through which the members of a powerful and influential elite (van Dijk 1993) position themselves to construe 'justice' in quite distinct ways. In fact, as already observed, not only is what is enacted and articulated in this powerful institutional setting of great significance, but it is also how language is worded that matters.

It is now time to tie up some remaining loose ends. Crucially, one of the strengths of corpus-assisted methodologies to the analysis of discourse lies in its deep potential for interdisciplinary endeavours where the combination of research based on corpus linguistics methods and techniques and research in other disciplines is essential in achieving insights into complex issues whose contours are somewhat hazy. Drawing on corpus evidence, as Hardt-Mautner in her seminal paper observed, is fundamental in redefining "the nature of 'interpretation', turning it from an introspective undertaking into an empirical one" (Hardt-Mautner 1995: 22). However, it must be pointed out that any empirical undertaking should not turn into a mere technical (or counting) exercise but one that brings with it new meaning and significance to discourse; from this perspective contextual knowledge is fundamental to a deeper understanding of complex societal issues.

In the paper, a number of issues have been raised and brought to the fore both theoretically and methodologically at the intersection between methods, tools, and disciplinary boundaries. In particular, the research suggests that while meanings of what is right as instantiated by parliamentary members of the government in office at the time under study tend to construe justice as a set of normative and pragmatic tools 
to legitimise national interest and values, especially by privileging a system of fairness for its own citizens, members of the parties in opposition to that government tend to construe justice as a set of moral tools - that is, obligations and duty in accordance with international law and principles. Clearly, this should not be understood as simple binary oppositions but as dynamic relations to be unpacked across variables of space and time. This has been brought about both by the investigation of the evaluative construction it is $*$ right, as well as by a cursory analysis of moral and its typical collocational behaviour. Indeed, languaging rightness allows for the expression of different world-views through which immigration-related issues are not only approached but also, and critically, acted upon in powerful institutional settings where ideology and power lie at the very heart of decision-making, particularly on politically sensitive issues such as (im)migration.

\section{References}

Adams, Karen. 1999. Deliberate dispute and the construction of oppositional stance. Pragmatics 9 (2): 231 248.

Ancarno, Clyde. 2018. Interdisciplinary approaches in corpus linguistics and CADS. In Charlotte Taylor \& Anna Marchi, Corpus Approaches to Discourse, 130-156. London: Routledge.

Aristotle. 2000. Nicomachean Ethics. Trans. D. Crisp. Cambridge: Cambridge of University Press.

Austin, John L. 1962. How to Do Things With Words. Oxford: Oxford University Press.

Bakhtin, Michail M. 1981. The Dialogic Imagination: Four Essays by M.M. Bakhtin. Austin/TX: University of Texas Press.

Baker, Paul. 2006. Using Corpora in Discourse Analysis. London: Continuum.

Baker, Paul. 2012. Acceptable bias? Using corpus linguistics methods with critical discourse analysis. Critical Discourse Studies 9 (3): 247-56.

Baker, Paul \& McEnery, Tony (eds) 2015. Corpora and Discourse Studies. London: Palgrave MacMillan.

Bayley, Paul (ed.) 2004. Cross-cultural Perspectives on Parliamentary Discourse. Amster- dam/Philadelphia: John Benjamins.

Bayley, Paul. 2004. Introduction: The whys and wherefores of analysing parliamentary discourse. In Paul Bayley (ed.). Cross-cultural Perspectives on Parliamentary Discourse,1-44. Amsterdam/Philadelphia: John Benjamins.

Bayley, Paul. 2007. Perhaps .... But: Expanding and contracting alternative viewpoints. Textus XX (1): 117-136 
Bayley, Paul \& Bevitori, Cinzia. 2009. Just war or 'just' war: Arguments for doing the right thing. In John Morley \& Paul Bayley (eds), Corpus-assisted discourse studies on the Iraq conflict: Wording the war. New York: Routledge.

Bevitori, Cinzia. 2004. Interruption in British and Italian parliamentary debates. In Paul Bayley (ed.), Crosscultural Perspectives on Parliamentary Discourse, 87-110. Amsterdam/Philadelphia: John Benjamins.

Bevitori, Cinzia. 2005. Attribution as evaluation: a corpus-based investigation of quotations in parliamentary discourse. ESP ACROSS CULTURES 2: 7-20.

Bevitori, Cinzia. 2006. Speech Representation in Parliamentary Discourse. Rhetorical Strategies in a Heteroglossic Perspective: A Corpus-based Study. In Maurizio Gotti \& John Flowerdew, Studies in Specialized Discourse, 155-180. Bern: Peter Lang.

Bevitori, Cinzia. 2007. Engendering conflict? A corpus-assisted analysis of women MPs positioning on the war in Iraq. Textus XX (1): 137-158.

Bevitori, Cinzia. 2010. Gendered discourses on war at the intersection between party affiliation and institutional role: The case of legislative Assemblies. Invited speech at Gender and Language - BAAL Special Interest Group, Gender and Corpus Linguistics Event, University of Lancaster, 30 March 2010.

Bevitori, Cinzia. 2018. Crossing boundaries: Investigating 'fair' in British parliamentary debates on $\mathrm{Im} /$ migration. In E. Di Martino \& Blaxill, L. (eds), Aspects of Political Language in the Age of "PostDemocracy" and Beyond. Textus XXXI (1): 165 - 185. [https://www.rivisteweb.it/doi/10.7370/89450]

Biber, Douglas \& Conrad, Susan 1999. Lexical bundles in conversation and academic prose. In Hilde Hasselgård, \& Signe Oksefjell Ebeling (eds), Out of corpora, 181-190. Amsterdam/Atlanta GA: Rodopi.

Biber, Douglas, Conrad, Susan \& Cortes, Vivien. 2004. If you look at ...: Lexical bundles in university teaching and textbooks. Applied Linguistics 25 (3): 371-405.

Boulton, C. J., Sweetman, J. F., Limon, D. W., Barclay, H. M., McKay, W. R. , Hastings, A. J., Willoughby, R. J. \& Keith, B. P. (eds) 1989. Erskine May's Treatise on the Law, Privileges, Proceedings and Usage of Parliament. London: Butterworths.

Eriksen, E.O. 2016. Three Conceptions of Global Political Justice. Globus Report 1. Oslo: ARENA Centre for European Studies. Available at http://www.globus.uio.no/publications/globus researchpapers/2o16/20r6-orglobus-research-paper-eriksen.html [Accessed July 2016]

Fairclough, Norman. 1992. Discourse and Social Change. Cambridge: Polity Press.

Fraser, Nancy. 2005. Reframing justice in a globalized world. New Left Review 36: 69-88.

Halliday, Michael A. K. [1961] 2002a. Categories of the theory of grammar. In J.J. Webster (ed.), On

Grammar, Vol. 1, in The collected works of M. A. K. Halliday, 37-94. London: Continuum.

Halliday, Michael A. K. [1985] 2002b. Dimensions of discourse analysis: Grammar. In J.J. Webster (ed.), On Grammar, Vol. 1, in The collected works of M. A. K. Halliday, 261-286. London: Continuum.

Halliday, Michael A.K. 2005. On matter and meaning: the two realms of human experience.

Linguistics and the Human Sciences 1 (1): 59-82. 
Halliday, Michael A. K. \& James, R. Martin, J. (eds.). 1993. Writing Science: literacy and discursive power. London: Falmer Press.

Halliday, Michael A.K. \& Matthiessen, Christian M.I.M. 2004. An Introduction to Functional Grammar. London: Arnold.

Hardt-Mautner, Gerlinde 1995. Only connect. Critical discourse analysis and corpus linguistics. University of Lancaster. Available at http://www.comp.lancs.ac.uk/computing/research/ucrel/tech_paperHardt Mautner [accessed 5 April 2005].

Harris, Sandra. 2001. Being politically impolite: extending politeness theory to adversarial political discourse. Discourse and Society 12: 451-472.

Hunston, Susan. 2011. Corpus Approaches to Evaluation. Phraseology and Evaluative Language. London/New York: Routledge.

Kelly, Paul. 2003. Ideas and Policy Agendas in Contemporary Politics. In Patrick Dunleavy, Andrew Gamble, R. Heffernan \& G. Peele (eds), Developments in British Politics 7, 242-260. Basingstoke: Palgrave MacMillan.

Kilgarriff, Adam, Rychlý, Pavel, Smrz, Pavel \& Tugwell, Davif. 2004. Sketch Engine. Proceedings of the 11th EURALEX International Congress, 105-116.

Ihalainen, Pasi, Ilie, Cornelia \& Palonen, Kari (eds) 2016. Parliament and parliamentarism: A comparative history of disputes about a European concept. New York: Berghahn Books.

Ilie, Cornelia. 2004. Insulting as (un) parliamentary practice in the British and Swedish

Parliaments. A rhetorical approach. In Paul Bayley (ed.), Cross-cultural perspectives on parliamentary discourse, 45-86. Amsterdam/Philadelphia: John Benjamins.

Ilie, Cornelia. 2006. Parliamentary Discourses. In Keith Brown (ed), Encyclopaedia of Language and Linguistics. 2nd Edition, Vol. 9, 188-197. Oxford: Elsevier.

Ilie, Cornelia (ed.) 2010. European parliaments under scrutiny: Discourse strategies and interaction practices, Amsterdam: John Benjamins.

LeBar, Mark \& Slote, Michael. 2016. Justice as a Virtue, In Edward N. Zalta (ed), The Stanford Encyclopedia of Philosophy. Spring Edition.Available at: https://plato.stanford.edu/entries/justice-virtue [accessed March 2018].

Lemke, Jay L. 1985. Ideology, Intertextuality, and the notion of register. In J. D. Benson \& W. S.Greaves (eds), Systemic Perspectives on Discourse, 275-294. Norwood-NJ: Ablex.

Lemke, Jay L. 1992. Interpersonal meaning in discourse: value orientation. In Martin Davies \& Louise Ravelli (eds), Advances in Systemic Linguistics, 82-104. London/New York: Pinter.

Martin, James, R. 2000. Beyond exchange: appraisal systems in English. In Susan Hunston \& Geoff Thompson (eds), Evaluation in Text: Authorial Stance and the Construction of Discourse, 142-75. Oxford: Oxford University Press. 
Martin, James, R. \& Rose, David. 2003. Working with Discourse: Meaning beyond the clause. London: Continuum.

Martin, James R. \& White, Peter. 2005. The language of Evaluation: Appraisal in English. London: PalgraveMacMillan.

Martin-Rojo, Luisa \& van Dijk, Teun A. 1997. There was a problem and it was solved!: Legitimating the expulsion of migrants in Spanish parliamentary debates. Discourse and Society 8(4): 523-567.

Mau, Steffen, Braband, Heike,Laube, Lena \& Roos, Christof (eds) 2011. Liberal States and the Freedom of Movement. Selective Borders, Unequal Mobility. London: Palgrave-MacMillan.

Miller, Donna R. 1999. Meaning up for grabs: Value-orientation patterns in British parliamentary debates on Europe. In Jef Verschueren (ed.), Language and Ideology: Selected Papers from the 6th International Pragmatic Conference, Vol. 1, 386-404. Antwerp/Belgium IPrA, Antwerp.

Miller, D. R., Bayley, P., Bevitori, C., Fusari, S. \& Luporini, A. 2014. 'Ticklish trawling': The limits of corpus assisted meaning analysis. In S. Alsop \& S. Gardner (eds), Language in a Digital Age: Be Not Afraid of Digitality: Proceedings from the 24th European Systemic Functional Linguistics Conference and Workshop. Coventry: Coventry University. Available at https://curve.coventry.ac.uk/open/items/7b5b94aa-6984-48ad-b29a9a8e9483fa2d [Accessed March 2016]

Miller, Donna R. \& Johnson, Jane H. 2013. 'Register-Idiosynchratic' Evaluative Choice in Congressional Debate: A corpus-assisted comparative study. In Lise Fontaine, Tom Bartlett \& Gerard O'Grady (eds), Systemic Functional Linguistics: Exploring Choice, 432-452. Cambridge: Cambridge University Press.

Miller, Donna R. \& Johnson, Jane H. 2014. Evaluative Phraseological choice and speaker party/gender. A corpus-assisted comparative study of 'register idiosyncratic' meaning in Congressional debate. In Geoff Thompson \& Laura Alba-Juez (eds), Evaluation in Context, 345-366. Amsterdam/Philadelphia: John Benjamins.

Morley, John \& Bayley, Paul (eds). 2009. Corpus-assisted discourse studies on the Iraq conflict: Wording the War. New York: Routledge.

Oxford English Dictionary. Oxford: Oxford University Press. OED online at http://www.oed.com

Partington, Alan. 2004. Corpora and Discourse: A most congruous beast. In Alan Partington, John Morley \& Louann Haarmann (eds), Corpora and Discourse, 11-20. Bern: Peter Lang.

Partington, Alan, Duguid, Alison \& Taylor, Charlotte. 2013. Patterns and Meanings in Discourse. Theory and Practice in Discourse Studies (CADS). Amsterdam: John BenjaminPublishing.

Partington, Alan \& Morley, John. 2004. At the heart of ideology: Word and cluster/bundle frequency in political debate. In B. Lewandowska-Tomaszczyk (ed.). Practical Applications in Language and Computers. Frankfurt am Main: Peter Lang, 179-192.

Plato. 2003. The Republic. Trans. D. Lee. London: Penguin Classics.

Rawls, John. [1971] 1999. A Theory of Justice. Cambridge MA: Harvard University. 
Reyes, Antonio. 2011. Strategies of legitimization in political discourse: From words to actions. Discourse and Society 22 (6): 781-807.

Roget's Thesaurus Of English Words And Phrases. 2000. Kirkpatrick, B. (ed.). London: Penguin Reference Books.

Russel, Meg. 2016. Parliament: A significant constraint on Government. In Richard Heffernan, C. Hay, Meg Russel \& Philip Cowley (eds), Developments of British Politics 10, 99-121. London: Palgrave-McMillan.

Sandel, Michael. 2009. Justice. What's the right thing to do? New York: Farrar, Straus and Gireaux.

Scott, Michael. 2015. WordSmith Tools version 6. Liverpool: Lexical Analysis Software.

Silverstein, Michael. 2004. Cultural concepts and the language-culture nexus. Current Anthropology 45 (5), 621652.

Sinclair, John. 2004. Trust the text: language, corpus and discourse. London \& New York Routledge.

Stubbs, Michael. 1996. Text and Corpus Analysis: Computer-Assisted Studies of Language and Culture. Oxford: Blackwell Publishing.

Stubbs, Michael \& Gerbig, Andrea. 1993. Human and Inhuman Geography: On the Computer-Assisted Analysis of Long Text. In Michael Hoey (ed.), Data, Description, Discourse. Papers on the English Language in Honour of John McH Sinclair on his Sixtieth Birthday, 64-85. London: Harper Collins.

Taylor, Charlotte \& Marchi, Anna (eds) 2018. Corpus Approaches to Discourse. A Critical Review. London and New York: Routledge.

Thompson, Geoff \& Hunston, Susan. 2006. System and Corpus: two traditions with a common ground. In G. Thompson and S. Hunston (eds), System and Corpus: Exploring connections, 1-14. London: Equinox.

van Dijk, Teun A. 1993. Elite Discourse and Racism: Newbury Park (CA): Sage Publications.

van Dijk, Teun A. 2000. Parliamentary debates. In Ruth Wodak \& Teun A. van Dijk (eds), Racism at the Top: Parliamentary Discourses on Ethnic Issues in Six European States, 45-78. Klagenfurt: Drava Verlag.

van Leeuwen, Theo. 1996. The representation of social actors. In Carmen Caldas-Coulthard \& Michael Coulthard (eds), Texts and Practice: Readings in Critical Discourse Analysis, 32-70. London/New York: Routledge.

van Leeuwen, Theo \& Wodak, Ruth, 1999. Legitimizing immigration control: A discourse historical analysis, Discourse Studies 1(1): 83-118.

Walzer, Michael. 1983. Spheres of justice: A defence of pluralism and equality. Oxford: Robertson.

Walzer, Michael. 2011. On Humanitarianism: Is Helping Others Charity, or Duty, or Both? Foreign Affairs 90 (4): 69-80.

Widdowson, Henry .G. 1995. Discourse analysis: A critical view. Language and Literature 4 (3): 157-172 .

Wodak, Ruth \& van Dijk, Teun A. (eds) 2000. Racism at the Top: Parliamentary Discourses on Ethnic Issues in Six European States. Klagenfurt: Drava Verlag. 
Wilson, John. 1990. Politically Speaking: The pragmatic analysis of political language. Oxford: Blackwell.

Yeo, Colin. 2017. The hostile environment: what is it and who does it affect? Free Movement. Available at https://www.freemovement.org.uk/hostile-environment-affect/ [Accessed February 2018]

Zotti, Antonio. Forthcoming, 2020. The United Kingdom's Immigration Policy: Enduring Exceptionalism and the Renewed Quest for Control. In M. Ceccorulli, E. Fassi \& S. Lucarelli (eds), Justice on the Move: Evaluating Migration Governance in the European Space. London: Palgrave. 